\title{
Factors Affecting Financial Literacy among Budding Entrepreneurs
}

\author{
Aruna Polisetty ${ }^{1, *}$, Nammi Lalitha $^{2}$, Hari Babu Singu ${ }^{3}$ \\ ${ }^{1}$ Department of Finance, Symbiosis Centre for Management Studies, Nagpur; Constituent of Symbiosis International University, Pune, \\ India \\ ${ }^{2}$ Department of Finance, GITAM Institute of Management, GITAM University, Visakhapatnam, India \\ ${ }^{3}$ Symbiosis Institute of Business Management, Nagpur, Constituent of Symbiosis International University, Pune, India
}

Received July 16, 2021; Revised August 5, 2021; Accepted September 21, 2021

\section{Cite This Paper in the following Citation Styles}

(a): [1] Aruna Polisetty, Nammi Lalitha, Hari Babu Singu, "Factors Affecting Financial Literacy among Budding Entrepreneurs," Universal Journal of Accounting and Finance, Vol. 9, No. 5, pp. 1085 - 1092, 2021. DOI: 10.13189/ujaf.2021.090518.

(b): Aruna Polisetty, Nammi Lalitha, Hari Babu Singu (2021). Factors Affecting Financial Literacy among Budding Entrepreneurs. Universal Journal of Accounting and Finance, 9(5), 1085 - 1092. DOI: 10.13189/ujaf.2021.090518.

Copyright $(2021$ by authors, all rights reserved. Authors agree that this article remains permanently open access under the terms of the Creative Commons Attribution License 4.0 International License

\begin{abstract}
An entrepreneur is often driven by a quest for innovation and creativity in a market, thus creating competition. The competition will create wealth, leading to improved living standards for individuals and the economy at large. Moreover, innovation and creation result in new and superior products that enable modern markets to be developed. However, the enthusiasm to become an entrepreneur is not the sole driving factor. One must know the importance of financial literacy. Besides, the negative stigma due to the COVID-19 pandemic ruined many lives and impacted businesses with less money due to the reduction of clientele; also, it had impacted budding entrepreneurs (at early start-up stages, and hardly have had experience between 1-3 years) with fewer opportunities to make money. That reduced the willingness of entrepreneurs to invest capital in the business due to raging losses. The current article presents the importance of financial literacy for budding entrepreneurs. To find and measure the financial literacy among budding entrepreneurs, the data were distributed to 223 entrepreneurs; however, 179 were finally used for analysis due to several reasons mentioned in the research methodology. The data was collected from five districts of the South region of India (Kerala, Andhra Pradesh, Karnataka, Telangana, and Tamil Nadu) and the snowball technique is used in the analysis. The study revealed that most budding entrepreneurs lack proper financial literacy. The study found that Financial Skills, Financial Knowledge, Financial Attitude, Social Interactions \& Past
\end{abstract}

Experiences, Financial Support \& Guidance directly influenced Financial Literacy levels among entrepreneurs. The study also suggests that aspiring entrepreneurs should be given practical financial training sessions; it should be made mandatory.

Keywords Entrepreneur, Financial Skills, Financial Knowledge, Financial Attitude, Social Interactions \& Past Experiences, Financial Support \& Guidance

\section{Introduction}

The primary goal of Entrepreneurship is not to make a profit but rather to create value. The crux of entrepreneurship influences individual endeavours at the micro-level and the economy at the macro level. It creates enormous opportunities to build up new ventures innovatively and offer opportunities to the unemployed; thus, it stimulates economic growth. There are many opportunities for budding entrepreneurs because of the vast young population in India. With a median age of 29, in the year 2020, India is the world's youngest country. This is an opportunity as well as a challenge for the development of a country. However, according to a report released by The Hindu [1], India presently has over 48 million small businesses, twice over the number compared to the US, which is about 23 million. India's future is 
brighter due to a handful of entrepreneurial opportunities for those who possess entrepreneurial skills and can undertake innovative endeavours.

In this context, financial literacy plays an important role in budding entrepreneurs. Appropriate training for entrepreneurs to instil financial literacy later empowers them to explore and implement innovative endeavours. The more financial literacy, the greater would be beneficial and can foresee macro-economic environment and income shocks Klapper et al. [2]. Slighter financial literacy would limit entrepreneurs' abilities, thus leading to incorrect financial decisions. Chen et al. [3] Managing money plays a crucial role in influencing personal and organisational front decisions. But most budding entrepreneurs lack knowledge in basic financial allied services such as accounting, budgeting, taxation, and reporting. Financial literacy helps the entrepreneur know what it is worth. It helps to understand where it heads for, what constraints face it, and what options are available to handle the constraints. But budding entrepreneurs are most susceptible in their financial decision-making. Yet, a finance expert or a banker can help budding entrepreneurs to raise finance. But an entrepreneur must build a competitive advantage that distinguishes between finance $\&$ its allied services, understanding profitability and managing finances.

\section{Research Gap}

Financial literacy brings a secure environment for inspiring entrepreneurial attitude, yet it is important to know what elements promote financial literacy among entrepreneurs. The present study generates insights into financial literacy among budding entrepreneurs. A systematic literature review was conducted in India and the global level to analyse the focus of previous studies. It was observed that many studies focused on the adoption of financial practices, accounting, and budgetary practices its influence on financial performance. However, few studies focused on financial behaviour, how they track their earnings, returns, repayments, and knowledge on the availability of sources of capital. In addition, very few studies focused on business competencies and management skills to manage the business. Most of the studies focused on young entrepreneurs; however, regardless of age, the studies found the advantages of having financial literacy (knowledge of accounting, costing, budgeting, and capital allocation) on running business operations. Financial literacy and performance of the business again depend on the controlling factors such as the firm's size, age, and experience of the entrepreneur.

Few studies focused on the need for professional financial training for the business's success because many entrepreneurs lacked the ability to analyse risk and return, tax rates, inflation, interest rates, compound interest rates, etc. Moreover, many studies statistically proved the significant and positive relationship between financial literacy on performance. This paper aims to study the factors influencing financial literacy among entrepreneurs: Financial Skills, Financial Attitude, Financial Knowledge, Social Interactions \& Experience, Financial Support, and Guidance. To what extent have these factors influenced the Financial Literacy of entrepreneurs. The findings would ponder sculpting strategies for promoting financial literacy levels to continue entrepreneurial endeavours.

\section{Review of Literature}

Isern et al., Kojo Oseifuah, Fatoki, Ali et al. [4-7] found that generally, small entrepreneurs have little knowledge about financial literacy and that level of knowledge was not enough to understand and manage finances and to take financial decisions on time because the recent study which was conducted in Africa shows that $85 \%$ of the entrepreneurs failed in their operations because of poor management decisions and low financial literacy levels. Ahmad et al. [8] carried study management skills and entrepreneurial success of SMEs in the private sector. This study collected data from 1423 Washington state residents using stratified random sampling technique and considered knowledge, behaviour, and attitude towards financial literacy. The main objective of the study was to assist consumers in making financial decisions. Salome and Memba [9] observed a positive influence of the financial performance on the profits, return on assets and liquidity. This study emphasised evaluating the impact of financial literacy training on the financial performance of the soapstone business in Kenya. The significant areas of study were improvement in investment decisions, budgeting, cash flow management, record keeping and debt management skills, and access to cheap finance with favourable repayment terms.

Akande et al. [10] considered in their study knowledge on budgeting to examine budgeting performance. The data was collected using a structured questionnaire and applied chi-square to test the hypothesis and concluded that there was a significant impact on the financial performance of the firms and the use of budgeting. Fatoki [11] observed 34 micro-enterprises and opined that most of the entrepreneurs have minimum knowledge on financial terminologies such as savings, loans, investments, collateral, taxes, and stock market etc. However, these entrepreneurs could not understand the core financial terms like lending, debt financing etc. Harrison Kinyua [12] established the relationship between financial literacy and maintenance of books of accounts, credit management, and loan repayment by MSMEs. They also analysed to find out the relationship between budgeting skills and financial statement analysis and found a positive relationship between them. Muruga and John [13] 
observed the effect of financial literacy on the performance of the firms led by youth based on budgeting, training in financial literacy, debt management, bookkeeping and performance criteria on profitability, growth, accumulation of assets, compliance to government regulations etc., and found a positive relationship between financial literacy and performance of the firms.

Eniola and Anthony Abiodun [14] examined the influence of financial literacy on the overall performance of SMEs in Nigeria with a sample of 100; they opined that financial literacy is one of the essential skills required for an entrepreneur to be successful. Husniyati Ali [15] have conducted a study by collecting data from 100 respondents (SMEs) and it is found that knowledge on accounting and costing helps SMEs to manage their firms effectively even though the firm's financial conditions are not that good and favourable and discussed that the advantages of knowledge on financial literacy. Ali et al. [16] opined that entrepreneurs should have minimum financial literacy knowledge like accounting, costing, and budgeting for development, growth, and sustainability and compete with the competitive world. It is stated that these entrepreneurs acquired adequate funds and invested to earn sufficient revenues. Furthermore, the author stated that financially literate entrepreneurs have higher income and savings and are successful in planning, maintaining lower debts. Mashizha et al. [17] also stated that the financial literacy levels of small and medium enterprises are very low.

Anshika et al. [18] attempted to study different levels of financial literacy like general, specific, and overall levels among 309 Micro and small enterprises (SMEs) using the ordered logit model. The observations of this study revealed that the age of the entrepreneurs has a significant impact on the three levels of financial literacy. This study further focussed on examining the impact of financial literacy on the performance of the MSEs and observed that the entrepreneurs with a high level of financial literacy have been earning huge profits comparatively. Baohua Liu et al.[19] analysed the impact of financial literacy of the entrepreneurs of Small and medium enterprises (SMEs) on innovation using a large sample from China and found that financial literacy was positively correlated with innovation. It is also observed that gender is one of the influencing factors as male entrepreneurs promote more innovations comparatively with their counterparts. It is also stated that firm's size and risk tolerance are also positively associated with innovation.

\section{Theoretical Framework}

All entrepreneurs need adequate financial literacy to launch and subsequently grow their businesses. Access to loans or credit lines is a key factor in the process of expansion for small enterprises. A financially literate business owner is more likely to fully control their business. However, many businesses fail due to low financial literacy levels. Understanding the importance of savings, knowing financial sources, analysis of risk and return is very important for the business's success. As shown in Figure 1 below, the study has considered five factors and their influence on financial literacy.

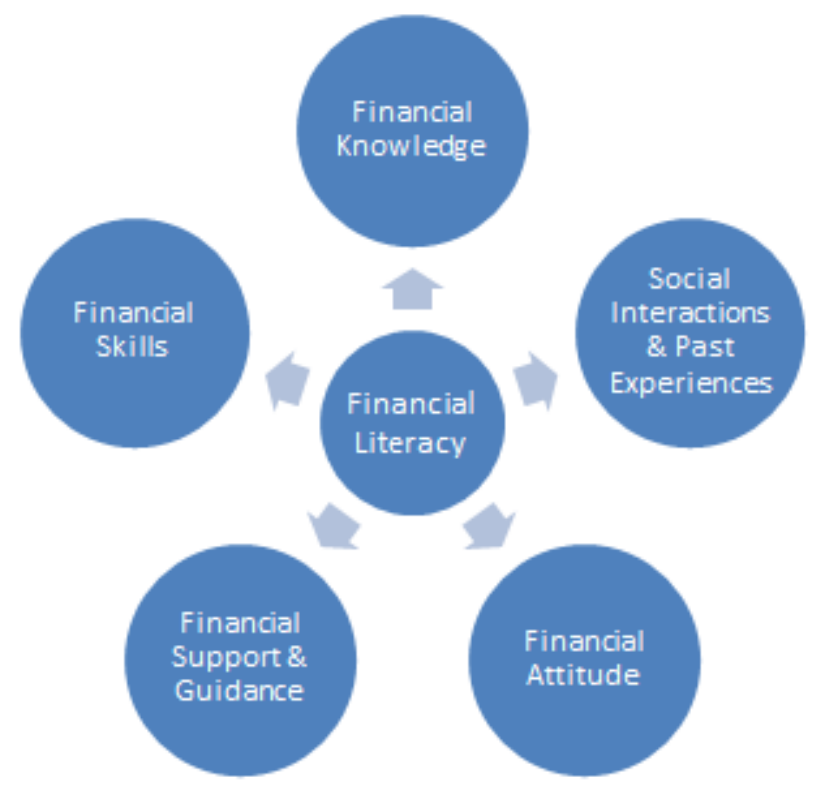

Chart 1. Financial Literacy and its Influencing Factors (Author Compilation)

\section{Financial Skills}

Financial skills refer to adequate skills in understanding financial concepts, such as understanding the priority of savings rather than spending, choosing financial instruments, analysing financial instruments, and diversifying savings. All entrepreneurs need adequate financial skills to understand various sources for raising finance. The ability to analyse to procure finance at a lower cost also prioritises savings, thus resulting in subsequent growth.

Thus, we recommend

H1: Financial skills positively correlated to and predict financial literacy.

\section{Financial Attitude}

The financial attitude factor impacts the financial literacy level of an entrepreneur, and it refers to the emotional and perceptual judgment of an entrepreneur in financial matters. It deals with entrepreneur behaviour in tracking their earnings, acquiring funds, repayment of dues on time. It studies how systematic their financial behaviour is toward financial goals; thus, a financial attitude of an entrepreneur influences financial literacy 
level. Therefore, the entrepreneurs who hang on to better financial goals with a positive financial attitude would be more prepared to accomplish proficiency in financial literacy Albeerdy and Gharleghi [20]. There is a positive relationship between financial attitude and financial literacy Chaulagain and Ramesh Prasad [21]; conversely, a negative financial attitude would result in a sub-standard financial literacy Atkinson and Messy [22]

Thus, we suggest

H2: Financial attitude is positively correlated to and predicts financial literacy.

\section{Financial Knowledge}

Researchers often use the terms financial literacy and financial knowledge interchangeably; however, they are not identical. According to Huston [23], researchers differentiate financial knowledge and financial literacy; the former is a theoretical understanding of financial matters. The latter is both a theoretical understanding of financial matters and their application. Financial knowledge has a significant influence on financial literacy Chaulagain and Ramesh Prasad [24], and it facilitates and enriches the level of financial literacy Lusardi et al. [25]; Lusardi et al. [26] \& Moore [27] it helps in effective money management, making financial decisions, and achieving financial stability.

Thus, we propose

H3: Financial knowledge is positively correlated to and predict financial literacy.

\section{Social Interactions \& Past Experience}

Many ways can affect financial literacy among individuals. Financial socialisation in educational institutions explains the financial literacy level of the individuals Grohman [28] According to John [29] \& Brown et al. [30], the influence of peer group on financial literacy is crucial because college-going students and youth spend more time with their peers. Nguyen [31] identified a positive association between better and improved financial literacy levels with one's friends and the community.

Thus, we assume:

H4: Social interaction influence is positively correlated and predicts financial literacy

\section{Financial Support and Guidance}

Financial support \& guidance refer to adequate financial backing from the family, friends, and peers and their guidance about financial matters. The present study wanted to propose and measure the hypothesis to understand how far the financial support and guidance from their family members, friends, peers would influence financial literacy among entrepreneurs.
Thus, we undertake:

H5: Financial support and guidance influence is positively related and predicts financial literacy

\section{Research Methodology}

The present study adopted a descriptive research design; the sample chosen was entrepreneurs who started their start-ups, small businesses dealing with manufacturing and services located in Kerala, Andhra Pradesh, Karnataka Telangana, and Tamil Nadu. Snowball sampling is adopted for data collection. A pilot study was conducted on 30 entrepreneurs in Andhra Pradesh and Kerala. After a one-on-one conversation over the telephone few suggestions were considered, and minor modifications (Financial Support and Guidance related questions were added at this stage) were made in the questionnaire. After all modifications questionnaire was distributed among 223 entrepreneurs online: 192 of them filled and submitted, while few of them mailed about their closure due to pandemic. Thirteen questionnaires were removed from the analysis since they chose the same options for almost all questions. One hundred seventy-nine (179) questionnaires were finally analysed for the study; however, this was adequate for data analysis; according to Tinsley and Tinsley, Anderson and Gerbing, Ding et al. [32-34], the minimum criteria for running Structural equation modelling were 100-150.

The data were analysed through Structural equation modelling using Smart PLS 3.0. The study finalised Financial Literacy (FLY) as the dependent variable, and Financial Skills (FS), Financial Attitude (FA), Financial Knowledge (FK), Social Interactions \& Experience (SIPE), and Financial Support and Guidance (FSG) are independent variables. The final questionnaire consisted of 6 constructs and 19 measurement items (FS-4; FA-4; FK-3; SIPE-2; FSG-2; FLY-4). The relevant items were chosen, modified, and validated by experts.

\section{Data Analysis and Findings}

To measure the internal consistency among the variables, Cronbach's Alpha coefficient, Composite Reliability (CR) and Rho-A were assessed. As shown in Table 1, all values met the criteria. Also to validate and meet the criteria, convergent validity was measured; the average variance extracted (AVE) values, P-values, $\mathrm{t}$-values met the required criteria. According to table no.1, the AVE of the constructs were FLY (0.824), FS (0.750), FA (0.768), FK(0.825), SIPE(0.737), and FSG(0.739) the outer loadings of variables FLY $(0.856, .0 .891, .0 .903, .0 .835), \quad$ FS $(0.853,0.866, .0 .859, .0 .888), \quad$ FA $(0.865, .0 .889, .0 .878, .0 .874)$, FK ( 0.856,. 0.786,. 0.835), SIPE $(0.723, .0 .751)$, FSG $(0.753, .0 .725)$. 
Table 1. Reliability and Validity Construct

\begin{tabular}{|c|c|c|c|c|c|}
\hline & $\begin{array}{c}\text { Number of } \\
\text { Items }\end{array}$ & $\begin{array}{c}\text { Cronbach's } \\
\text { Alpha }\end{array}$ & rho_A & $\begin{array}{c}\text { Composite } \\
\text { Reliability }\end{array}$ & AVE \\
\hline Financial Skills & 4 & 0.948 & 0.950 & 0.997 & 0.750 \\
\hline Financial Attitude & 4 & 0.855 & 0.859 & 0.926 & 0.768 \\
\hline Financial Knowledge & 3 & 0.905 & 0.906 & 0.952 & 0.825 \\
\hline $\begin{array}{c}\text { Social Interactions \& } \\
\text { Past Experience }\end{array}$ & 2 & 0.900 & 0.901 & 0.913 & 0.737 \\
\hline Financial Support and Guidance & 2 & 0.789 & 0.791 & 0.907 & 0.739 \\
\hline Financial Literacy & 4 & 0.942 & 0.946 & 0.960 & 0.871 \\
\hline
\end{tabular}

Table 2. Heterotrait-Monotrait Correlations

\begin{tabular}{|c|c|c|c|c|c|}
\hline & Financial Skills & $\begin{array}{c}\text { Financial } \\
\text { Attitude }\end{array}$ & $\begin{array}{c}\text { Financial } \\
\text { Knowledge }\end{array}$ & $\begin{array}{c}\text { Social } \\
\text { Interactions \& } \\
\text { Experience }\end{array}$ & $\begin{array}{c}\text { Financial } \\
\text { Support and } \\
\text { Guidance }\end{array}$ \\
\hline Financial Skills & & & & & \\
\hline Financial Attitude & 0.614 & & & & \\
\hline Financial Knowledge & 0.634 & 0.574 & & & \\
\hline $\begin{array}{c}\text { Social Interactions \& Past } \\
\text { Experience }\end{array}$ & 0.516 & 0.478 & 0.528 & & \\
\hline Financial Support and Guidance & 0.542 & 0.465 & 0.507 & 0.497 & \\
\hline Financial Literacy & 0.666 & 0.578 & 0.633 & 0.587 & 0.670 \\
\hline
\end{tabular}

Table 3. Model Fit Indices

\begin{tabular}{|c|c|}
\hline Fit Indices & Results \\
\hline Chi-Square & $(0.000)$ DF-95 \\
1.579 \\
Chi-Square/degrees of freedom $\left(\mathrm{x}^{2} / \mathrm{d} . \mathrm{f}\right)$ & 0.904 \\
Comparative Fit Indices (CFI) & 0.931 \\
The goodness of Fit Indices (GFI) & 0.909 \\
Adjusted Goodness of Fit Indices (AGFI) & 0.921 \\
Normal Fit Index (NFI) & 0.933 \\
Incremental Fit Index (IFI) & 0.960 \\
Tucker Lewis Index (TLI) & 0.061 \\
\hline
\end{tabular}

The measurement model was assessed employing structural equation modelling Byrne [35]. The initial model exhibited a satisfactory model fit. The final measurement model offered a good fit as per the recommended levels: Normed $\mathrm{X}^{2}=1.579$; Goodness-of-fit Index (GFI) $=0.931$; Adjusted Goodness of Fit Index $(\mathrm{AGFI})=0.909$; Confirmatory Fit Index (CFI) $=0.904 ;$ Incremental Fit Index (IFI) $=0.933$; Tucker-Lewis Index (TLI) = 0.96; and Root Mean Square Error of Approximation (RMSEA) $=0.061$ Hoelter, Hu and Bentler; Iacobucci [36-38] refer to Table 3 for Model fit indices.

Path coefficient, and p-values among the constructs (Table 3) are: $\mathrm{FS}=>\mathrm{FLY}(.28, .000)$; FA $=>$ FLY $(.28, .000)$; $\mathrm{FK}=>\mathrm{FLY} \quad(.27,0.002) ; \quad \mathrm{SIPE}=>\mathrm{FLY} \quad(.29,0.068)$; $\mathrm{FSG}=>\mathrm{FLY}(0.32,0.045)$. The analysis shows that FS, FA, FK, SIPE, and FSG influenced FLY positively. Direct and total effects are shown in Figure 2, and the study has no indirect effects. Because the study has no mediation variable, the total and direct effects are the same.

As shown in Table 4, the statistical analysis reveals that the R-Square value of FLY is 0.628 and the adjusted R-Square value 0.617 . The analysis shows that $62.8 \%$ of the variances in the FLY is predicted by the independent variables FS, FA, FK, SIPE, FSG.

Table 4. Path Coefficients, $P$ Values

\begin{tabular}{|c|c|c|}
\hline & $\begin{array}{c}\text { Path } \\
\text { Coefficients }\end{array}$ & P-values \\
\hline Financial Skills_> Financial Literacy & 0.28 & 0.000 \\
\hline $\begin{array}{c}\text { Financial Attitude_> Financial } \\
\text { Literacy }\end{array}$ & 0.28 & 0.000 \\
\hline $\begin{array}{c}\text { Financial Knowledge_> Financial } \\
\text { Literacy }\end{array}$ & 0.27 & 0.002 \\
\hline $\begin{array}{c}\text { Social Interactions \& Experience_> } \\
\text { Financial Literacy }\end{array}$ & 0.29 & 0.068 \\
\hline $\begin{array}{l}\text { Financial Support and Guidance_> } \\
\text { Financial Literacy }\end{array}$ & 0.32 & 0.045 \\
\hline
\end{tabular}




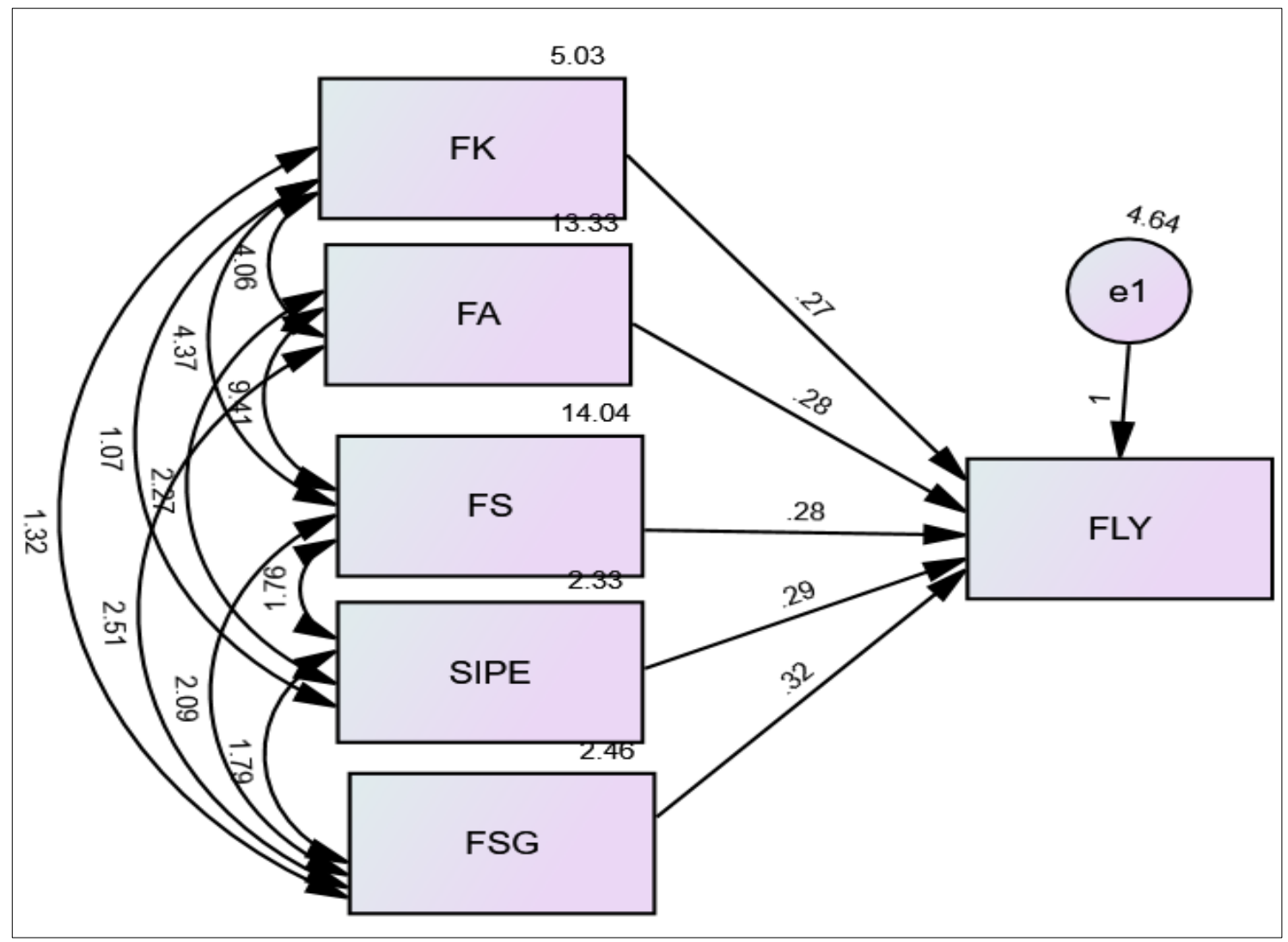

Figure 2. Path diagram

Table 5. R Square, R Square Adjusted Values

\begin{tabular}{|c|c|c|c|}
\hline Model & R & R Square & Adjusted R Square \\
\hline 1 & $.792^{\mathrm{a}}$ & .628 & .617 \\
\hline \multicolumn{4}{|l}{ a. Predictors: (Constant), FSG, FS, FK, FA, SIPE } \\
\hline
\end{tabular}

The financial landscape is dynamic, and it has many participants. Many factors influence the quickly changing environment. Lack of basic financial skills is the reason for business failures. The Financial hardship of budding entrepreneurs is studied in the present article. The total effects of the path analysis showed surprising results of financial literacy among budding entrepreneurs. Financial support and guidance from peers and parents and social interactions and past experiences highly impact financial literacy. However, other factors such as Financial Attitude, financial skills, financial knowledge also played a role in the financial literacy.

\section{Implications and Conclusions}

The present study revealed that most budding entrepreneurs lack proper financial literacy. Besides, the data analysis disclosed that Financial Skills, Financial Attitude, Financial Knowledge, Social Interactions \& Experience, and Financial Support and Guidance directly influence financial literacy levels. Therefore, the present study consists of a literature review and various determinant factors that influence financial literacy and entrepreneurship.

Managerial Implications: the aspiring entrepreneurs should be given practical financial training sessions. Financial guidance, support from family and peer groups, and general social interactions are limited to theoretical aspects; government authorities need certification programs for aspiring/budding entrepreneurs. It should be made mandatory for all who want to enter the business field. Financial training must be more focused on practical sessions rather than theoretical lectures. However, there must include the theoretical understanding of basic financial allied service concepts such as financial planning, time value of money, risk and return trade-off, budgeting, cash management, differentiation between cash flow and profitability, etc.

Policy Recommendations: This paper brings out the best potentials needed for an entrepreneurial aspirant. It gives confidence and suggests entrepreneurial endeavours to undertake new projects and help policymakers and applied researchers focus on missing gaps in financial literacy programs. Furthermore, along with theoretical lectures, it is advised to incorporate practical sessions for improving financial literacy into the academics irrespective of programmes undertaken; after all, financial literacy is much needed at every stage of life.

Scope for Future Research: Future research may be focused more on formulating strategies and policies to improve financial literacy levels among entrepreneurial 
aspirants.

\section{REFERENCES}

[1] Girija Shivakumar, "India is set to become the youngest country by 2020" The Hindu, Retrieved from https:/www.thehindu.com/news/national/india-is-set-to-be come-the-youngest-country-by-2020/article4624347.ece

[2] Klapper, L. F., Lusardi A., Panos G.A., "Financial Literacy and the Financial CrisisPolicy Research" WPS No. 5980, World Bank. 2012.

[3] Chen H., Volpe R.P., "An analysis of personal financial literacy among college students," Financial Services Review, vol.7 (2), 1998.

[4] Isern, J., Agbakoba, A., Flaming, M., Mantilla, J., Pellegrini, G., \& Tarazi, M. (2009). Access to Finance in Nigeria: Microfinance, Branchless Banking and SME Finance. https://www.cgap.org/sites/default/files/CGAP-Access-toFinance-in-Nigeria-Microfinance-Branchless-Banking-and -SME-FinanceJan-2009.pdf.

[5] Kojo Oseifuah, E., "Financial literacy and youth entrepreneurship in South Africa", African Journal of Economic and Management Studies, 2010, Vol. 1 No. 2, pp. 164-182. https://doi.org/10.1108/20400701011073473.

[6] Fatoki O., "The financial literacy of micro-entrepreneurs in South Africa," Journal of Social Sciences, vol.40(2), pp. 151-158, 2014.

[7] Ali H., Omar E.N., Nasir H.A., Osman, M.R., "Financial literacy of entrepreneurs in the small and medium enterprises," In Proceedings of the 2nd advances in business research international conference, pp.31-38, 2018.

[8] Ahmad Zahiruddin Yahya1, Choong Kwai Fatt, Abdullah Sanusi Othman, Ishak Abdul Rahman, Jumaat Moen, "Management skills and entrepreneurial success of small and medium enterprises (SMEs) in the services sector," TECHNICAL REPORT 03-39, Financial Literacy in Washington State Technical Report \#03-39,2003/2011.

[9] Salome N. K., Memba F., "Financial Literacy and Financial Performance of Art and Craft Business", 2014.

[10] Akande, Olusola O., Yinus Oluwaseun., "In Fluence of budgeting system on Entrepreneurial Business performance: perspective of Small business Owner in lagos state Nigeria," Journal of Business and Management (IOSR-JBM) e-ISSN: 2278-487X, ISSN: 2319-7668, Volume 16, Issue 6, PP 58-64, 2014.

[11] Fatoki O., "The financial literacy of micro-entrepreneurs in South Africa," Journal of Social Sciences, vol.40(2), pp. 151-158, 2014.

[12] Harrison Kinyua (2015), Financial literacy and its impact on loan repayment by small and medium entrepreneurs, International Journal of Economics, Commerce and Management United Kingdom, vol. III, issue 3, 2015, http://ijecm.co.uk/ ISSN 23480386

[13] Muruga and John, "Effects of Financial Literacy on
Performance of Youth-Led Enterprises”, 2015.

[14] Eniola, Anthony Abiodun, "Financial literacy and SME firm performance," Department of Management and Accounting, Faculty of Management Sciences Ladoke Akintola University of Technology, Ogbomoso, Oyo State, Nigeria, 2016.

[15] Husniyati Ali, Emi Normalina Omar, Hanisah Abu Nasir, Muhamad Rahimi Osman, "Financial Literacy of Entrepreneurs in the Small and Medium Enterprises," Proceedings of the 2nd Advances in Business Research International Conference, pp.31-38, 2017.

[16] Ali H., Omar E.N., Nasir H.A., Osman, M.R., "Financial literacy of entrepreneurs in the small and medium enterprises," In Proceedings of the 2nd advances in business research international conference, pp.31-38, 2018.

[17] Margaret Mashizha, Mabutho Sibanda, Blessing Maumbe, "Financial literacy among small and medium enterprises in Zimbabwe" The Southern African Journal of Entrepreneurship and Small Business Management Vol 11, No 1 | a241 |, https://doi.org/10.4102/sajesbm.v11i1.241

[18] Anshika A., Singla G., Mallik, "Determinants of financial literacy: Empirical evidence from micro and small enterprises in India," Asia Pacific Management Review, 2019, https://doi.org/10.1016/j.apmrv.2021.03.001

[19] Baohua Liu, Jiancheng Wang, Kam C Chan, The impact of entrepreneurs' financial literacy on innovation within small and medium-sized enterprises, 2020, https://doi.org/10.117 7\%2F0266242620959073.

[20] Albeerdy M.I., Gharleghi B., "Determinants of the financial literacy among college students in Malaysia," International Journal of Business administration, vol. 6 (3) pp.15-24, 2015.

[21] Chaulagain, Ramesh Prasad, "Financial Literacy for Increasing Sustainable Access to Finance in Nepal," NRB Working Paper 31, Nepal Rastra Bank, Research Department, 2015.

[22] Atkinson A., Messy FA, "Measuring financial literacy: results of the OECD/international network on financial education (INFE) pilot study," Working Papers on Finance, Insurance and Private Pensions, vol. 15, pp.1-73, 2012.

[23] Huston S., "Measuring financial literacy," Journal of Consumer Affairs, vol.44 (2), pp.296-316, 2010.

[24] Chaulagain, Ramesh Prasad, "Financial Literacy for Increasing Sustainable Access to Finance in Nepal," NRB Working Paper 31, Nepal Rastra Bank, Research Department, 2015.

[25] Lusardi A., Carlo de Bassa Scheersberg, "Financial Literacy and High-Cost Borrowing in the United States NBER Working Paper 18969, 2013.

[26] Lusardi A., Michell O.S., "Financial literacy and retirement preparedness: Evidence and implications for financial education." Business Economics: The Journal of the National Association of Business Economists, vol. 42 (1), pp. 35-44, 2007.

[27] Moore D., "Survey of Financial Literacy in Washington State: Knowledge, Behaviour, Attitudes, and Experiences," Technical Report No. 03-39, Olympia, WA: Social and 
Economic Sciences Research Centre, Washington State University, 2003.

[28] Grohmann, A., Kouwenberg R., Menkhoff L., "Childhood roots of financial literacy," Journal of Economic Psychology, 2015.

[29] John D.R., "Consumer socialisation of children: A retrospective look at twenty-five years of research," Journal of Consumer Research, vol. 26 (3), pp.183-213, 1999.

[30] Brown B.B., Mounts N., Lamborn S.D., Steinberg L., "Parenting practices and peer group affiliation in adolescence," child development, pp.467-482, 1993.

[31] Nguyen K. N., "High School Seniors Financial Knowledge: the Impact of Financial Literacy Classes and Developmental Assets Thesis", University of Arkansas, 2013

[32] Tinsley H. E., Tinsley D.J., "Uses of Factor Analysis in Counseling Psychology Research,” Journal of Counseling Psychology, vol. 34, pp.414-424, 1987, https://doi.org/10.1 037/0022-0167.34.4.414

[33] Anderson, J. C., Gerbing, D.W., "Structural Equation
Modeling in Practice: A Review and Recommended Two-Step Approach," Psychological Bulletin, 103, 411, 1988, https://doi.org/10.1037/0033-2909.103.3.411

[34] Ding, L., Velicer W. F., Harlow L. L. "Effects of Estimation Methods, Number of Indicators per Factor, and Improper Solutions on Structural Equation Modeling Fit Indices," Structural Equation Modeling: A Multidisciplinary Journal, vol.2, pp.119-143, 1995, https://doi.org/10.1080/10705519 509540000

[35] Byrne, B.M., "Structural Equation Modeling with AMOS. Basic Concepts," Applications and Programming. Lawrence Erlbaum, Mahwah, 2001.

[36] Hoelter, JW, "The analysis of covariance structures: Goodness-of-fit indices," Socio. Methods Res. 11 (3), $325 \mathrm{e} 344,1983$.

[37] Hu, L.-T., Bentler, P.M., "Evaluating model fit. In: Hoyle, R.H. (Ed.), Structural equation modelling," Concepts, issues, and applications. Sage, London, pp. 76e99, 1995.

[38] Iacobucci, D., 2010. "Structural equations modelling: fit indices, sample size, and advanced topics," J. Consum. Psychol. 20 (1), 90e98, 2010. 